\title{
Вплив рівня розвитку освіти та права на економічний потенціал країни
}

\author{
Микола Ткач * А; Анатолій Лойшин А; Сергій Кондратюк ${ }^{\text {A }}$ \\ А Національний університет оборони України імені Івана Черняховського, пр-кт Повітрофлотський 28, м. Київ, 03049, Україна
}

Received: December 01, 2020 | Revised: December 09, 2020 | Accepted: December 31, 2020

JEL Classification: 125, 012, 015.

DOI: $10.33445 /$ sds.2020.10.6.6

\begin{abstract}
Анотація
Стаття $€$ цікавою для фахівців в економічній сфері, які займаються дослідженням проблем розвитку економічного потенціалу країни. Метою статті $€$ дослідження закономірностей у розвитку економічного потенціалу країни та його залежність від ступеню розвитку освіти, науки та права в державі. Поставлене наукове завдання вирішувалося шляхом порівняння економічного розвитку деяких країн світу та розвитку їхньої системи освіти та права.

В процесі досягнення мети дослідження використані наступні методи наукового пізнання: історичної аналогії, аналізу, синтезу, індукції, дедукції, системного підходу.

Проведений аналіз джерел свідчить, що питанням впливу освіти та права на розвиток економіки країн приділяється надзвичайно велика увага всесвітньо відомих вчених економістів ще з початку XVII ст. і закінчуючи теперішнім часом. В даній науковій праці показано, що саме розвиток освіти та їі масове розповсюдження $\epsilon$ передумовою розвитку науки та лібералізації права, а в сукупності і передумовою економічного розвитку країни. На прикладі таких розвинутих світових країн, як США, Великобританія, Франція, Німеччина, та ін. виявлені певні фактори, які сприяли розвитку способів передачі і розвитку знань в цих країнах. Проведено аналіз рейтингу університетів світу, світового індексу правосуддя та економічного благополуччя деяких країн світу.
\end{abstract}

Ключові слова: економічний потенціал, наука, освіта, університет, право, правосуддя.

\section{Постановка проблеми}

В кінці XVIII та протягом XIX ст. в країнах Західної Європи та США відбувався справжній науковий "бум", паралельно 3 яким, надзвичайно швидкими темпами, проходила індустріалізація цих країн та становлення їхнього економічного і воєнного домінування у світі. Слід зазначити, що індустріалізація не була би можливою без розвитку науки та техніки адже саме наука дозволила змінити способи і методи ведення господарства. Відбувалися нові відкриття в хімії, фізиці, медицині та ін., які і дозволили цим країнам стати домінуючими в світі. Саме в цей період з'являються нові джерела енергії, машини та механізми, які почали заміщати живу силу. Цікавим $€$ те, що саме в країнах Європи та США, а не в інших, почався економічний розвиток та індустріалізація. Це говорить проте, що в цих країнах існували певні передумови, які i спровокували такий розвиток подій. Дослідження цих передумов з точки зору історичного формування системи освіту, науки і права є надзвичайно важливим. Саме такий підхід допоможе розкрити сутність не тільки економічного розвитку країн, а і розвитку суспільства в цілому. Розвиток освіти відноситься до системи розвитку людського капіталу, а розвиток права створює умови для реалізації потенціалу існуючого людського капіталу. Ці дві системи (освіта і право) $є$ не від'ємними для ефективного розвитку та використання людського капіталу, а розуміння

* Corresponding author: к.т.н., начальник кафедри оборонного менеджменту, e-mail: nyck1985@ukr.net, ORCID: 0000-0002-8832-1268 
їхнього впливу та взаємозв' язку $є$ надзвичайно

важливою задачею.

\section{Аналіз останніх досліджень та публікацій}

Аналіз існуючих досліджень показує, що питанням соціально-економічного розвитку, як окремих країн, так і світу, присвячена велика кількість наукових праць. Питання впливу освіти, науки та права на економічний розвиток тривожило розум вчених з давніх часів. Питанням впливу освіти на економічне благополуччя країни присвячені праці таких вчених як Р. Солоу та Е. Денісона, А. Маршала, Г. Беккера, М. Блауга, Л. Хансена та ін. Питанням впливу правової системи держави та держави на економіку країни також присвячена велика кількість наукових досліджень в переліку яких праці всесвітньо відомих вчених економістів - А. Сміта, Ф. Гаєка, Б. Бруцкуса, К. Поппера та ін.

Актуальність питань економічного розвитку країн та могутності їхніх держав актуальна і в наш час, причому цікавість до цих питань з часом тільки зростає. У зв'язку $з$ цим існує потреба у продовженні досліджень закономірностей та залежностей їхнього розвитку в різних соціальних системах.

\section{Постановка завдання}

Актуальність питань економічного розвитку країн та могутності їхніх держав актуальна і в наш час, причому цікавість до цих питань 3 часом тільки зростає. У зв'язку з цим існує потреба у продовженні досліджень закономірностей та залежностей їхнього розвитку в різних соціальних системах.

Метою статті $\epsilon$ виявлення закономірностей впливу освіти, науки та права на розвиток економічного потенціалу країни.

\section{Виклад основного матеріалу}

Саме XIX ст. $€$ цікавим в рамках даного дослідження адже в цей період відбувався світовий "бум" - змінювалися соціальнополітичні устрої держав, промислова революція, демографічний бум та наукова революція яку світ ще не знав до цього. Такі події значною мірою вплинули на розвиток економічного потенціалу країн, які переходили до капіталістичної економіки.

На кінець XIX початку XX ст. країни, які стали на шлях капіталістичного розвитку та індустріалізації отримали значну перевагу у порівнянні з країнами, які цього не змогли зробити. В першу чергу це було пов'язано 3 розвитком освіти, ростом грамотності населення, науки та техніки. Винаходи XIX ст. почали змінювати способи ведення господарства, з'явилися нові види діяльності, нові машини та джерела енергії які раніше людство не використовувало, удосконалювалося старе та з'являлися нові види озброєння.

Бум на наукові відкриття та перехід економіки на капіталістичні рейки $\epsilon$ закономірним результатом буржуазноліберальних революцій в Європі та інших країнах які розвивалися за європейським зразком. Приватна власність, ліберальний ринок, а також отримані свободи, які раніше не були доступними, збільшили можливості для широких мас населення, що викликало урбаністичний рух та відповідно збільшення міського населення, підвищення рівня освіти та ії масовості. У XIX ст. 90 \% всіх наукових відкриттів та винаходів було зроблено в чотирьох країнах, які на той час вже успішно проводили індустріалізацію своєї економіки (мал. 1). 


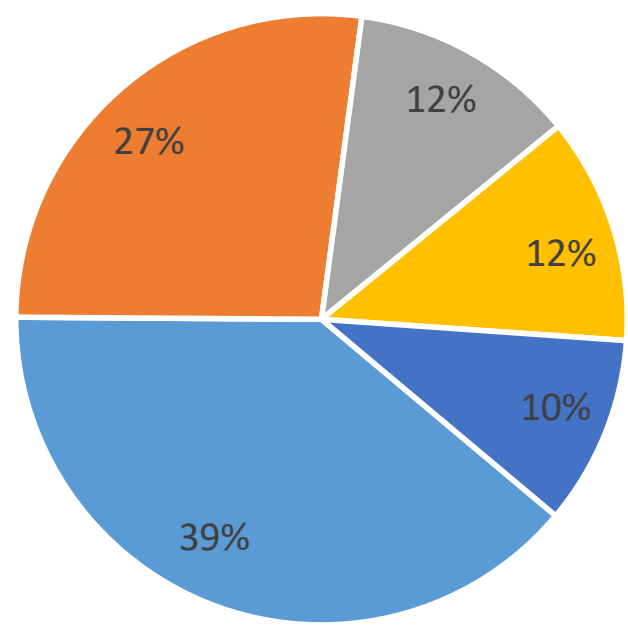

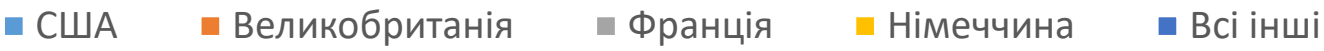

Малюнок 1 - Країни з найбільшою кількістю наукових відкриттів та винаходів у XIX ст.

Зрозумілим $€$ світове лідерство у наукових відкриттях США адже шлях країни до капіталізму дещо відрізняється від європейських країн. США були засновані 3 самого початку на принципах свободи та рівних можливостей для всіх громадян (звичайно не рахуючи рабів та корінні народи). Там не існувало феодального устрою, який формувався на протязі сотні років та монарха, який мав би всю повноту влади. Суспільство, після війни за незалежність в кінці XVIII ст., обирало владу на всенародному голосуванні, воно мало свою конституцію, яка засвідчувала їхнє право на свободу, захист свого житяя та власності. Звичайно це звучить дещо ідеалізовано адже з розвитком капіталізму в США все більше зміцнювалася влада монополістів - власників заводів, фабрик, залізничних доріг, банків та землі. Саме вони диктували свої умови і вирішували долі мільйонів робітників та селян. Але в порівнянні 3 монархічними та феодальними устроями, США здавалися оазисом свободи, що приваблювало підприємливих людей.

Слід зазначити, що винахідницький бум в деяких країнах Європи та США не міг виникнути на пустому місці, цьому мали передувати певні умови. До таких умов можна віднести розвиток освіти, науки та права.

Історія розвитку науки та способів передачі знань можна вести з давньої античності. Ще $з$ грецьких держав та Риму існували школи та гімназії в яких займалися вивченням філософії, математики, граматики, астрономії, геометрії, музики та військовій справі. Наприклад в Афінах в V ст. до н.е. кожен вільний громадянин вмів писати та читати. Все це позитивно вплинуло на розвиток науки, а особливо філософії та природничих наук. Напрацювання античних вчених в подальшому значно вплинуть на розвиток суспільства на Євразійському континенті.

У середньовічній Європі, як це не дивно звучить, опікуном науки та освіти стала церква. Саме при церквах відкривалися школи, а пізніше і університети, які займалися навчанням студентів. В першу чергу церква відбирала здібних студентів, навчала їх для поповнення своїх рядів. Тобто це була певна кадрова робота, яка мала забезпечити церкву кваліфікованими богословами, господарниками та забезпечити в подальшому нарощення могутності церкви та впливу її на всі сфери суспільного життя.

Перші університети в Європі почали з'являтися ще у XII ст. в Італії (Болонський 
університет), Англії (Оксфордський університет), Франції (Паризький університет). Навчання студентів в університетах сприяло розвитку уміння аналізувати, розвитку логіки мислення, знаходити суперечності в судженнях та прагненню з'ясувати суть тих чи інших речей. Саме такі навички і призводили в подальшому до розвитку наукової думки.

Станом на 1800 рік в західній Європі вже діяло біля 110 католицьких та біля 35 не католицьких гімназій та університетів. На території Священної Римської Імперії та Східної Європи 44 католицьких, 56 лютеранських та 35 кальвіністських університетів та гімназій [1]. Переважна більшість навчальних закладів знаходилися в таких країнах, як Великобританія, Франція, Італія, Німеччина, Іспанія, Португалія, Австрія та Швеція. В цей же період в США існувало вже 8 приватних університети, які існують і на теперішній час та входять до Ліги Плюща [2].

На початку XIX ст. країни західної Європи та США в рази переважали всі інші країни за кількістю навчальних закладів та рівнем освіти населення. Для порівняння в Японії університети почали з'являтися тільки в другій половині XIX ст. (1869 Кіотський університет, 1870 рік Ніігатський університет, 1873 рік університет Сінсю, 1875 рік Сідзуоцький університет, 1876 рік Хіросацький університет, 1877 рік Токійський університет). В Російській Iмперії на початок XIX ст. існувало 5 університетів з яких тільки 3 знаходилися на території сучасної Російської Федерації (1755 рік Московський державний університет, 1804 рік Казанський університет, 1819 рік СанктПетербурзький державний університет).

щодо Китаю, в якого одна 3 найдавніших державницьких традицій у світі, то на початок XIX ст. це була далеко відстала та з високим рівнем безграмотності населення країна. Тільки починаючи з 1889 року імператор Китаю Гуанг Ху та реформатори Канг Йовен і Ліанг Кішау опублікували дерективи, відповідно до яких в країні розпочалися реформи в сфері освіти. Ці реформи передбачали створення мережі шкіл, як державних, так і приватних. Також почали засновувати училища для підготовки педагогів. В 1897 році в Шанхаї було відкрито перший педагогічний університет, 1898 році таки й же університет відкрився в Пекіні.

Рівень освіти населення країни та рівень їі якості і сьогодні відіграє значний вплив на економічне становище країни. Сьогодні існує рейтинг університетів світу QS (QS World University Rankings) [3]. Університети оцінуються по шести показниках:

- наукова діяльність;

- викладання;

- думка роботодавців;

- кар'єрний потенціал;

- кількість закордонних студентів;

- кількість закордонних викладачів.

Для того що брати участь в оцінюванні університет повинен вести підготовку бакалаврів в мінімум двох предметних областях, наприклад:

- мистецтво;

- соціальні дисципліни;

- інженерне діло та технології;

- право;

- бізнес.

За рейтингом 2020 року [4] в першу десятку увійшли університети з США (Масачусецький університет технологій, Стенфорд, Гарвард, Каліфорнійський університет технологій, Чікагський університет), Великобританії (Оксфорд, Кембрідж, Лондонський університет, Імперський коледж Лондону) та Швейцарія (Швейцарський державний технологічний університет). Якщо розглянути історію цих навчальних закладів, то в деяких вона починається ще з XII ст. (Оксфорд), пізніші XVIII ст. (Стенфорд та Гарвард). Це говорить про їхній високий рівень, який існує вже на протязі століть та про те, що вони впливають на розвиток людства і сьогодні.

На сьогодні в світовому рейтингу якості освіти та науки Європейські університети та університети США продовжують лідирувати. Саме до них намагаються вступити найобдарованіші люди з усього світу, а за часту вони і залишаються в цих країнах. Рейтингові вищі навчальні заклади працюють, як магніт який притягує найкращих, дає їм знання, а самих обдарованих залишає для своєї країни. Виші $\epsilon$ не тільки лицем науки тієї чи іншої 
країни, але і серйозним гравцем на світовому ринку праці. Тому держави зацікавлені у розвитку своїх вишів та в їхніх випускниках. Самим обдарованим пропонуються місця, як в приватному, так і державному секторі. Це пов'язано з тим, що головним актором в любій соціальній системі, чи то Збройних Силах, чи уряді, чи транснаціональній компанії, чи на маленькому підприємстві залишається людина. Саме людина, а особливо обдарована, $\epsilon$ тим капіталом за який йде боротьба між світовими державами.

Показовим $\epsilon$ те, що країни 3 найуспішнішими навчальними закладами лідирують у кількості наукових відкриттів. Для аналізу буде цікавим рейтинг нобелівських лауреатів з різних країн світу. Звичайно провідні навчальні та наукові заклади приваблюють нобелівських лауреатів, як комфортне та статусне місце для роботи. В той же час висока концентрація видатних науковців в одному навчальному закладі збільшує вірогідність того, що в даному університеті буде зроблено нове наукове відкриття та з'явиться новий лауреат нобелівської премії.

В різних університетах використовується свій метод підрахунку наукових відкриттів, які були зроблені в їхніх стінах. Наприклад деякі університети не рахують нобелівських лауреатів, які перебували в їхніх стінах менше року (Колумбійський університет), а інші навпаки зараховують (Масачусецький університет). В Оксфорді не рахують причетність до наукового відкриття якщо лауреат нобелівської премії зробив ії до моменту прибуття в університет. В Єльському університеті облік нобелівських лауреатів взагалі ведеться тільки з 1955 року [5]. В зв'язку 3 цим скласти рейтинг університетів $€$ дещо важкою задачею, але в межах даного дослідження буде цікавим аналіз саме досягнень в науці країн в яких функціонують топ-університети. Таке порівняння покаже той потенціал який дозволяє країнам бути попереду в усіх сферах діяльності людини за рахунок висококласної освіти, розвитку науки i як наслідок передових наукових відкриттів.

Між ступенем економічного розвитку країни та розвитком ії науки та системи освіти $€$ певна кореляція. Якщо порівняти країни за часткою топових навчальних закладів у світовому рейтингу, часткою країни в загальному обсязі наукових відкриттів, часткою країни в світовому ВВП, то виявляється, що всі ці показники мають залежність (мал. 2). Найбільш яскраво цей зв'язок проглядається у США, Великобританії, Німеччині, Франції та Японії. Найбільше вражає те, що спеціальний адміністративний район КНР Гонконг, маючи населення 7,5 млн. чол. (103 місце в світі), площу 1106,4 км² (182 місце у світі) $є$ одним зі світових лідерів за кількістю найбільш рейтингових університетів та ВВП на душу населення (17 місце у світі) [6].

Розглянуті країни в сукупності виробляють 70 \% світового ВВП і в той же час мають найпотужніший науковий та освітній потенціал. Якщо розглядати їхні оборонні витрати, то за виключенням Гонконгу (оскільки він входить до складу КНР) вони входять до перших п'ятнадцяти у світовому рейтингу [10].

Наступним фактором, не менш важливим за освіту та науку, у розвитку економіки та новітніх технологій відіграє право. Саме право дає можливість забезпечити захист інтелектуальної власності науковцям, винахідникам та підприємцям. Якщо в країні функціонують прозорі правила, єдині для всіх без виключення, які гарантують безпеку приватної власності, в тому числі і інтелектуальної, це стимулює до розвитку особистості та приваблює талановитих і підприємливих людей. 


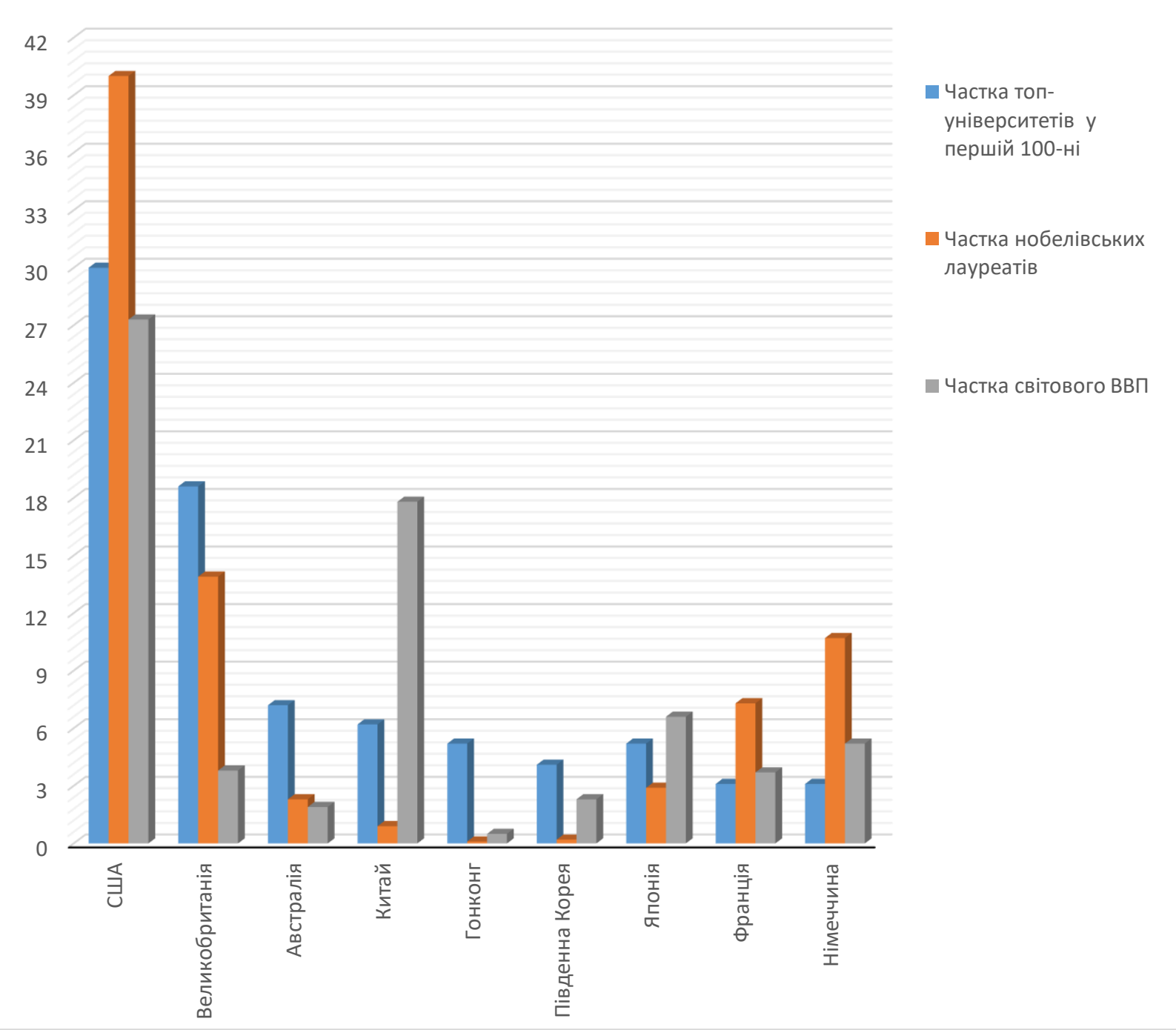

Малюнок 2 - Порівняння деяких країн за часткою в світовому ВВП на 2018 рік, за часткою топ-навчальних закладів першої сотні у світовому рейтингу та за часткою нобелівських лауреатів в даних країнах від загальної кількості [7-9]

Запорукою існування якісних економічних зв'язків $€$ функціонування правових норм та судової системи, а нехтування цим призводить до ослаблення економіки. Право $\epsilon$ соціально-нормативним регулятором та впливає на всі сфери суспільного життя. Оскільки економіку можна охарактеризувати як сукупність господарських зв'язків то, стійке функціонування цих зв'язків та їх розвиток повинен мати певне правове підґрунтя, що створює гарантії для суб'єктів господарювання та заохочує їх до співпраці. Саме право повинно забезпечувати справедливість шляхом правосуддя. Якщо розглянути індекс правосуддя та економічний розвиток різних країн то, можна знайти певну залежність. Організація World Justice Project (WJP) кожного року публікує індекс верховенства закону в різних країнах світу, їхній звіт спирається на результати опитувань більше ніж 130000 домашніх господарств і 4000 практикуючих юристів та експертів з усього світу. Так, останні три роки спостерігається тенденція до зменшення загальносвітового індексу правосуддя, але розглядаючи стан правосуддя безпосередньо в країнах можна стверджувати, що високий рівень правосуддя супроводжується високим рівнем розвитку економіки (мал. 3) [11]. 


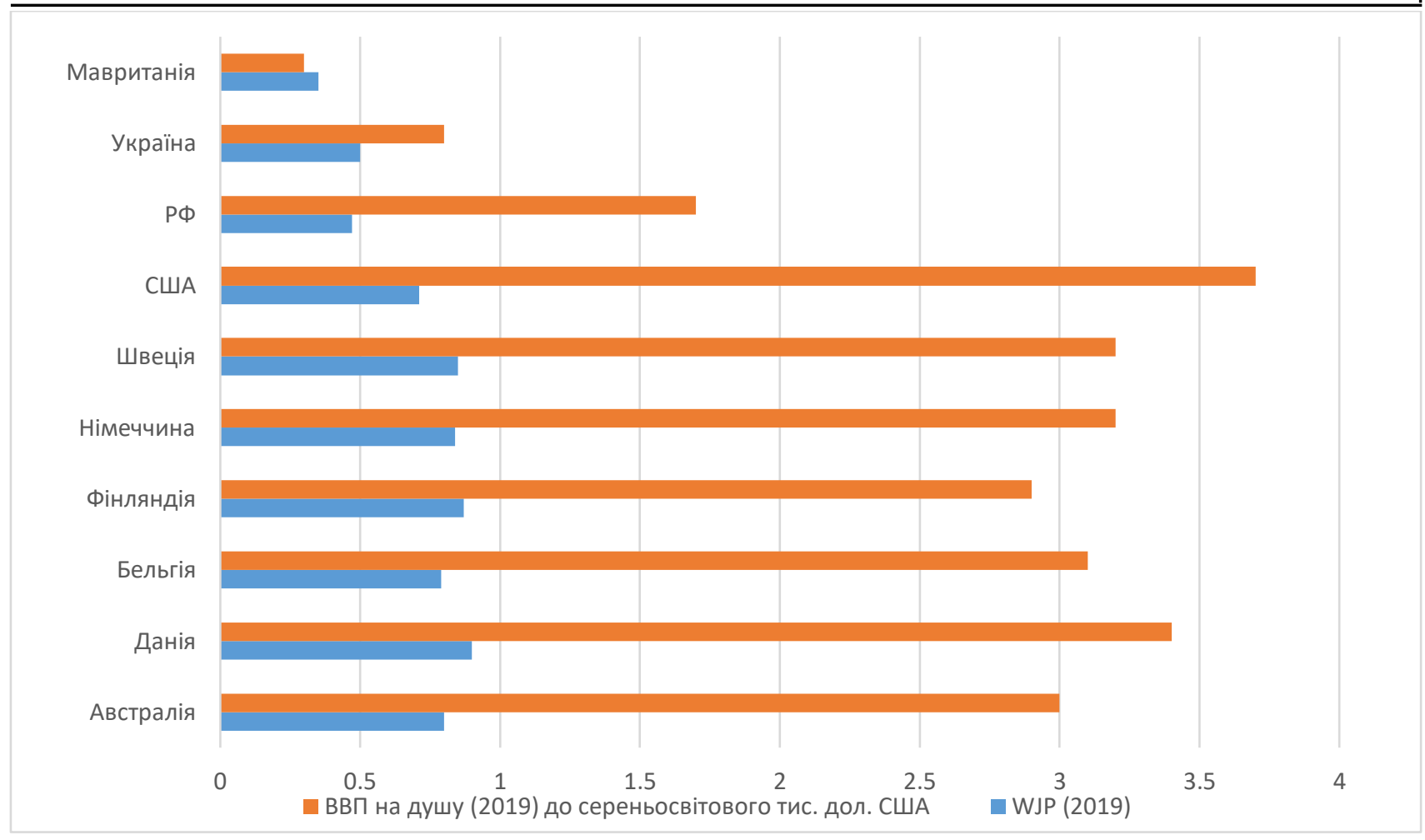

Малюнок 3 - ВВП на душу населення та індекс правосуддя деяких країн світу у 2019 році [11]

Всі країни, що мають високий рівень правосуддя мають високий рівень економічного розвитку, а країни з низьким рівнем правосуддя як правило $є$ економічно відсталими. Крім того економіка розвинених країн $€$ переважно високотехнологічною, а економіки відсталих країн з низьким рівнем правосуддя сировинними. Цікаво чи $є$ право драйвером розвитку економіки та чи може економіка розвиватися без розвитку права?

Перший звід законів відомий ще з 1792 року до н.е., автором якого був цар Вавілону Хаммурапі. Це перший з відомих нам випадків становлення права в країні та кодифікації законів. Згідно цим законам

\section{Висновки}

Проведене дослідження показує, що передумовою розвитку права, науки та економіки в Європі та країнах які розвивалися за "західною" моделлю $\epsilon$ багатовіковий розвиток освітніх інститутів. Перехід Європи на індустріальні рейки $є$ наслідком розвитку Європейської цивілізації починаючи ще 3 Античної Греції, продовженням цих традицій В католицьких Богословських навчальних закладах та в подальшому в сучасних правосуддя повинно було здійснюватися згідно єдиних правил, що мало зміцнити державність, владу царя, зменшити соціальну напругу та створити умови для розвитку держави.

3 плином часу та з розвитком суспільства удосконалювалося і право. Право та закони сьогодення в більшості країн світу $\epsilon$ вже більш лібералізованими та такими, що врівноважують права всіх верств населення не дивлячись на їхній соціальний статус, тобто відбулася певна демократизація права. Саме така тенденція і забезпечила, поряд з іншими чинниками, економічний розвиток передових демократичних країн світу.

навчальних закладах. Саме багатовікове накопичення знань та винайдення способу їх передачі та розвитку мислення і призвели до розвитку якості людського капіталу, що в подальшому вплинуло на всі сфери людського життя. Разом з розвитком рівня освіченості населення розвивалося і право, яка все більше ставало лібералізоване, але в той же час захищало права та свободи індивіда. Саме в найрозвиненіших країнах 
світу право забезпечує рівність всім верства населення, що створює стимул та можливості для розвитку.

В той же час існують країни, які не мають такої наукової спадщини як європейські країни, але $є$ не менше успішними (Японія, Китай, Південна Корея та ін.) Аналізуючи їхній шлях до економічного розвитку стає зрозумілим, що вони використали існуючий досвід та вікові напрацювання європейських країн, принаймні на початку їхнього шляху до успіху. В подальшому вони розвили свою систему освіти, яка багато в чому не поступається європейській. В той же час це не означає, що такі країни зможуть успішно розвиватися протягом десятиліть, чи століть, в умовах зменшенням впливу “західної" цивілізації на них.

\title{
Список використаних джерел
}

1. A History of the University in Europe. URL: https://books.google.ru/books?id=ZHMjzvAxH $F 0 C \& p g=P A 81 \# v=o n e p a g e \& q \& f=f a l s e \quad$ (дата звернення 22.08.2020).

2. Университеты США. URL: https://usainfo.com.ua/universitety/study/university (дата звернення 22.08.2020).

3. QS World University Rankings. URL: https://www.educationindex.ru/articles/unive rsity-rankings/qs/ (дата звернення 10.09.2020).

4. QS World University Rankings. URL: https://www.topuniversities.com/ universityrankings/world-university-rankings/ 2020 (дата звернення 10.09.2020).

5. Луговий В., Калашнікова С., Слюсаренко О., Таланова Ж. Нобелівські лауреати і топзаклади вищої освіти, країни та континенти з передовим університетським потенціалом. Вища освіта України. Київ. 2013. С 10-20.

6. Гонконг. URL: https://uk.wikipedia.org/wiki/ Гонконг (дата звернення 12.09.2020).

7. List of Nobel Laureates by Country. URL: https://www.jagranjosh.com/generalknowledge/list-of-nobel-laureates-by-country-
1495796462-1 (дата звернення 16.09.2020).

8. How many Nobel Prizes has the UK won? URL: https://fullfact.org/news/how-many-nobelprizes-has-uk-won/ (дата звернення 16.09.2020).

9. International Monetary Fund. URL: https://www.imf.org/external/pubs/ft/weo/2 019 (дата звернення 16.09.2020).

10. Military expenditure by country as percentage of gross domestic product, 1988-2019. SIPRI 2020. URL: https://www.sipri.org/ sites/default/files/Data\%20for\%20all\%20coun tries\%20from\%201988\%E2\%80\%932019\%20a s\%20a\%20share\%20of\%20GDP.pdf (дата звернення 22.09.2020).

11. World Justice Project. Rule of Law Index 2019 Insights. URL: https://worldjusticeproject. org/sites/default/files/documents/WJPInsights-2019-Single\%20Page\%20View_0.pdf (дата звернення 29.09.2020).

12. Tkach, M. (2020). Patterns of development of national power: historical experience of the world states. Political Science and Security Studies Journal, 1(1), 40-48. DOI: $10.5281 /$ zenodo. 4256820

\section{Влияние уровня развития образования и права на экономический потенциал страны}

\author{
Николай Ткач * А; Анатолий Лойшин А; Сергей Кондратюк А \\ *Corresponding author: к.т.н., начальник кафедры оборонного менеджмента, e-mail: nyck1985@ukr.net, ORCID: 0000-0002-8832-1268 \\ А Национальный университет обороны Украины, пр-кт Воздухофлотский, 28, г. Киев, 03049, Украина
}

\begin{abstract}
Аннотация
Статья интересна для специалистов в экономической сфере, которые занимаются исследованием проблем развития экономического потенциала страны. Целью статьи является исследование закономерностей в развитии экономического потенциала страны
\end{abstract}


и его зависимость от степени развития образования, науки и права в государстве. Поставленная научная задача решалась путем сравнения экономического развития некоторых стран мира и развития их системы образования и права.

В процессе достижения цели исследования использованы следующие методы научного познания: исторической аналогии, анализа, синтеза, индукции, дедукции, системного подхода.

Проведенный анализ источников показывает, что вопросам влияния образования и права на развитие экономики стран уделяется большое внимание всемирно известных ученых экономистов еще с начала XVII века и заканчивая настоящим временем. В данной научной работе показано, что именно развитие образования и его массовое распространение является предпосылкой развития науки и либерализации права, а в совокупности и предпосылкой экономического развития страны. На примере таких развитых мировых стран, как США, Великобритания, Франция, Германия и др. выявлены определенные факторы, которые способствовали развитию способов передачи и развития знаний в этих странах. Проведен анализ рейтинга университетов мира, мирового индекса правосудия и экономического благополучия некоторых стран мира.

Ключевые слова: экономический потенциал, наука, образование, университет, право, правосудие.

\title{
The impact of the level of development of education and law on the economic potential of the country
}

\author{
Mykola Tkach *A; Anatolii Loishyn A; Serhii Kondratiuk ${ }^{\text {A }}$ \\ *Corresponding author: PhD, Head of the Department Defence Management, e-mail: nyck1985@ukr.net, ORCID: 0000-0002-8832-1268 \\ A National Defense University of Ukraine named after Ivan Chernyakhovskyi, 28, Vozduhoflotsky, ave, Kyiv, 03049, Ukraine
}

\begin{abstract}
The article is of interest to experts in the economic field who study the problems of economic potential of the country. The purpose of the article is to study the patterns in the development of economic potential of the country and its dependence on the degree of development of education, science and law in the state. The set scientific task was solved by comparing the economic development of some countries and the development of their education and law. In the process of achieving the goal of the study, the following methods of scientific knowledge were used: historical analogy, analysis, synthesis, induction, deduction, system approach.

The analysis of sources shows that the impact of education and the right to economic development of countries is given great attention to world-renowned economists since the beginning of the XVII century. and ending in the present tense. This scientific work shows that the development of education and its widespread dissemination is a prerequisite for the development of science and liberalization of law, and in the aggregate and a prerequisite for economic development. On the example of such developed world countries as the USA, Great Britain, France, Germany, etc. identified certain factors that contributed to the development of methods of knowledge transfer and development in these countries. An analysis of the ranking of world universities, the world index of justice and economic well-being of some countries.
\end{abstract}

Keywords: economic potential, science, education, university, law, justice.

\section{References}

1. A History of the University in Europe. Available from: https://books.google.ru/ books?id=ZHMjzvAxHF0C\&pg=PA81\#v=onep age $\& q \& f=f a l s e$ (data zvernennya 22.08.2020).
2. University SSHA. Available from: https://usainfo.com.ua/universitety/study/ university (data zvernennya 22.08.2020).

3. QS World University Rankings. Available from: https://www.educationindex.ru/articles/uni 
versity-rankings/qs/ (data zvernennya 10.09.2020).

4. QS World University Rankings. Available from: https://www.topuniversities.com/universityrankings/world-university-rankings/2020 (data zvernennya 10.09.2020).

5. Luhovyy V., Kalashnikova S., Slyusarenko O., Talanova ZH. Nobelivs'ki laureaty i topzaklady vyshchoyi osvity, krayiny ta kontynenty $z$ perdovym universytet.s'kym potentsialom. Vyrshcha osvita Ukrayiny. Kyyiv. 2013. S 10-20.

6. Honkonh. Available from: https://uk. wikipedia.org/wiki/Гонконг звернення 12.09.2020).

7. List of Nobel Laureates by Country. Available from: https://www.jagranjosh.com/generalknowledge/list-of-nobel-laureates-bycountry-1495796462-1 (data zvernennya 16.09.2020).

8. How many Nobel Prizes has the UK won? Available from: https://fullfact.org/news/ how-many-nobel-prizes-has-uk-won/ (data zvernennya 16.09.2020).

9. International Monetary Fund. Available from: https://www.imf.org/external/pubs/ft/weo/ 2019 (дата звернення 16.09.2020).

10. Military expenditure by country as percentage of gross domestic product, 19882019. SIPRI 2020. Available from: https://www.sipri.org/sites/default/files/Dat a\%20for\%20all\%20countries\%20from\%2019 88\%E2\%80\%932019\%20as\%20a\%20share\%2 0of\%20GDP.pdf (data zvernennya 22.09.2020).

11. World Justice Project. Rule of Law Index 2019 Insights. Available from: https://worldjusticeproject.org/sites/default /files/documents/WJP-Insights-2019Single\%20Page\%20View_0.pdf (data zvernennya 29.09.2020).

12. Tkach, M. (2020). Patterns of development of national power: historical experience of the world states. Political Science and Security Studies Journal, 1(1), 40-48. DOI: 10.5281/zenodo.4256820 